\title{
13
}

\section{Taking the 'Just' Decision: Caseworkers and Their Communities of Interpretation in the Swiss Asylum Office}

\author{
Laura Affolter, Jonathan Miaz and Ephraim Poertner
}

\section{Introduction}

'Political and ethical issues are [...] found at the heart of public debate on asylum, which oscillates between a preoccupation with the management of migratory flows and the principle of protection of victims of persecution' (Fassin and Kobelinsky 2012: 469). This leads to tensions and aporia with which decision-makers are confronted in their everyday work. Fassin and Kobelinsky (2012: 470) identify three such aporia. The first refers to the need to simultaneously enhance the 'greater good' of the institution, i.e. asylum protection, and, at the same time, to challenge asylum applications and put them in doubt. The second has to do with what they define as 'the core value' in decision-making, as it is perceived by decision-makers themselves: 'that of

L. Affolter $(\bowtie)$

University of Bern, Bern, Switzerland

e-mail: laura.affolter@anthro.unibe.ch

J. Miaz

University of Lausanne, Lausanne, Switzerland

J. Miaz

University of Neuchatel, Neuchatel, Switzerland

e-mail: jonathan.miaz@unil.ch

E. Poertner

Department of Geography, University of Zurich, Zurich, Switzerland e-mail: ephraim.poertner@geo.uzh.ch 
the just decision' (ibid.). The term 'just', thereby, stands both for 'correctness' ${ }^{1}$ and 'fairness'. The third relates to the sanctioning of (moral) sentiments and their simultaneous importance as a means for determining the veracity of asylum claims as well as for rendering the institution 'human'. Related to this view, but more on a micro-level, much of the existing literature on street-level bureaucracies has dealt with practical decision-making dilemmas, particularly the juggling between, on the one hand, 'compassion and flexibility' and, on the other hand, 'impartiality and rigid rule-following' (Lipsky 2010: 15-16; see also Maynard-Moody and Musheno 2003).

However, what became apparent in our fieldwork is that these 'dilemmas' or aporia were generally not formulated as such by the caseworkers ${ }^{2}$ themselves. Fassin and Kobelinsky also underline this with regard to rapporteurs and magistrates in the French National Asylum Court (2012: 470). This, we argue, is not a coincidence. Hence, even if these different rationales of decision-making appear to stand in conflict, ways of resolving or at least reducing this tension are essential for caseworkers to do their job. In this chapter, we look at how this is done. Our aim is not to argue that these 'dilemmas' are never experienced as such by decision-makers. Sometimes they are. However, while this has been dealt with extensively in existing literature, not much attention has been paid to the fact that more often they are not. In this chapter, therefore, we deal with the 'non-experience' of dilemmas arising from what are from the 'outside' perceived as conflicting rationales of decision-making and the ways in which decision-makers deal with these rationales and make them fit. We argue that decision-makers' 'volitional allegiance' (Gill 2009: 215) with the asylum institution plays a crucial role thereby. This chapter develops an enquiry that illuminates how state officials themselves are governed (see also Gill 2016; Mountz 2010) through their involvement in particular groups within the office and the allegiances they develop towards them. Such an analysis involves talking to caseworkers about their 'desires', affiliations and their attempts to deal with the different exigencies of their work.

Just as Fassin and Kobelinsky (2012: 470) describe, for the caseworkers we spoke to decision-making is, ultimately, about taking 'correct' and 'fair' decisions. By drawing on their notion of the 'just decision' (encompassing both 'correctness' and 'fairness') we attempt to illuminate how asylum

\footnotetext{
${ }^{1 ' C}$ Correctness' of decisions is based on decision-makers' evaluations and not on that of applicants.

${ }^{2}$ By caseworkers we mean the people in the office who conduct interviews, collect evidence, write decisions and thus produce asylum cases.
} 
decision-makers in the Swiss administration make sense of their work: how they invoke notions of correctness and fairness with regard to decisionmaking practices, but also the greater good of the asylum institution in providing protection for those deserving it, and moral sentiments such as sympathy and compassion towards applicants and their stories. In this chapter, we show that how decision-makers make sense of what they do is influenced by their affiliations to and allegiances with what we call 'communities of interpretation'. ${ }^{3}$ We define 'communities of interpretation' as groups with which people identify. They have a 'shared repertoire' of knowledge and meanings (Wenger 2003) on how to interpret the law and (best) make sense of their work. These communities of interpretation evolve along the fissures between different asylum units and divisions, professional backgrounds, amount of working experience, and hierarchical positions. Different communities of these kinds coexist within the same office. They are crucial to the processes whereby notions of the 'just decision' develop and become shared amongst different subdivisions of the asylum office. Gill argues that state officials are not only 'compelled, disciplined or incentivised to act ["in accordance with state objectives"], but [are, furthermore,] ideationally conditioned to freely choose to conduct themselves' in such ways (Gill 2009: 219-220). We argue that these little communities of interpretation play an important role in this regard.

By placing the relationship between asylum caseworkers and (parts of) the office at centre stage in this article, we shed light on an issue that has received much less attention than, for instance, the relationship or encounter between asylum seekers and decision-makers (Jubany 2011; Gill 2009, 2016; Kobelinsky 2015; Maryns 2006; Probst 2011; Souter 2011), the social and legal conditions in which caseworkers apply the law (Miaz 2017), as well as the role of evidence in such encounters (Doornbos 2005; Good 2007; Gibb and Good 2013; Scheffer 2001). Thus, to understand why decision-makers do what they do, we argue that it is important to look at what decision-makers themselves claim that they 'do in the name of the state' (Gupta 1995: 376). It is here that their relationship with (part of) the office and their volitional allegiance to it become important.

After a short section on 'just decisions', where we explain how we analytically approach 'just' decision-making and describe our methods and data, we develop our argument in three main parts. The first two are organised

${ }^{3}$ We derive this term from Wenger's 'community of practice' (2003). 
around the two dimensions of what caseworkers and their superiors considered to make their work 'just': 'correctness' and 'fairness'. In the first part we discuss meanings ascribed to correct decision-making. We show that what 'correct' comes to mean is shaped by institutional constraints related to legality, productivity and accountability. Furthermore, we argue that other actors such as superiors, peers and magistrates of the Federal Administrative Court as well as imagined figures such as 'the Swiss people' or 'the tax payers' play an important role in shaping what it means to take a 'correct' decision. In the second part we analyse how caseworkers negotiate 'fairness'. We argue that different considerations-legal, organisational, relational, and moral-play into these negotiations and orient the caseworkers' practices and decision-making. In this section we also show that caseworkers develop particular ideas about the rightful positioning in this landscape of different (and at times conflicting) considerations (see also Liodden and Schneider, both this volume). In the last part of the chapter we show how developing such ideas is influenced by the communities of interpretation that decision-makers affiliate themselves with, or are affiliated with, as well as by the allegiances with these communities that they develop.

\section{Tracing the 'Just Decision'}

Following Laroche (1995) we understand 'just decisions' as social representations. Rather than approaching decision-making as being about an individualised notion of 'choice', we focus on how caseworkers and their supervisors speak about 'just' decisions and decision-making and try to make sense (and/or convey a certain sense to us, the researchers) of their work and the competing normative orders they have to manoeuvre within their daily work. Thus, in this chapter, we trace decision-makers' practical reasoning (Barnett 2011: 247) of 'just' decision-making through their verbal accounts when explaining, justifying and distancing themselves from certain events, which we relate back to everyday practices of asylum decision-making that we have observed and participated in.

Since 'just' decision-making is not directly observable but only constructed in the verbalisation of practices and practical knowledge, the main bulk of data in this chapter is conversational in nature. The verbal accounts we draw on are, on the one hand, conversations between us and caseworkers of the Swiss State Secretariat for Migration SEM, including semi-structured and open-ended interviews with caseworkers as well as informal conversations with them; and, on the other hand, conversations between different 
caseworkers that we observed, for instance, during so-called consulting sessions between superiors and their employees or training sessions for new caseworkers.

As described in the introduction, what constitutes 'just' decision-making is contested within the institution. Such contestations render the differing ideas of just decision-making visible. However, other aspects of what 'just' decision-making means may be self-evident within the institution. It is precisely such 'normalities' that we must attempt to grasp as ethnographers (see Breidenstein et al. 2013: 36). Yet, Shore and Wright also warn against becoming 'inured' to these normalities and claim that it is important to 'maintain sufficient critical distance to be able to keep asking fundamental questions about how [officials] conceptualise their worlds and what this means for theoretical debates' (2011: 15). This was something that all three of us struggled with. During our fieldwork, we all became inured to certain 'normalities'. ${ }^{4}$ Working together and sharing our thoughts and experiences has helped us to recognise our own 'normalities' and regain critical analytical distance. Our different disciplinary backgrounds-Ephraim Poertner is a human geographer, Jonathan Miaz a political scientist and Laura Affolter a social anthropologist-also proved enriching in this interpretative endeavour.

Asylum seekers must file their asylum application in one of the SEM reception centres, where they are submitted to the first steps of the procedure. The procedure comprises two asylum interviews. If the reception centre cannot decide on the asylum application within 90 days, the asylum seeker is allocated to a canton responsible for his or her accommodation and support. The procedure continues at the headquarters, where the file is further processed, usually by conducting the second interview, undertaking investigations and, ultimately, taking the decision.

We all did fieldwork in different units at the SEM headquarters and in one or two reception centres. Jonathan Miaz conducted his fieldwork between 2010 and 2012, Ephraim Poertner between 2012 and 2014 and Laura Affolter between 2013 and 2015..$^{5}$ Apart from our conversations with decision-makers, during our field-stays we also shadowed people in their daily work, went to coffee breaks and team meetings with them, sat in on

\footnotetext{
${ }^{4}$ However, maintaining and regaining distance is not difficult only because one becomes inured to one's interaction partners' normalities, but also because as researchers we become personally involved and develop relationships of trust with our interaction partners (see Van Maanen 1982).

${ }^{5}$ Whilst Poertner and Affolter mostly worked with German-speaking staff, Miaz predominantly dealt with French-speaking caseworkers.
} 
asylum interviews, took part in the training sessions for new employees, etc. Thus, we all collected vast amounts of material by combining an approach of 'classical' in-depth ethnography of one particular site with multi-sited ethnography. ${ }^{6}$ A lot of this material we shared with each other to write this chapter. We first pooled parts of our anonymised ethnographic material and then both jointly and separately categorised it.

\section{What 'Correctness' Means}

Decision-making in the SEM is, to a great extent, about taking 'correct' decisions. This can be seen in the following statement by a head of unit when describing her role as a superior:

I have to make sure my people write decent [ordentliche] and correct decisions. And enough. And exactly in this order. You see, for me quality is more important than quantity. ${ }^{7}$

But what do she and others mean by correct decisions? And how is the correctness of decisions checked and measured? These are the questions we deal with in this section. Furthermore, we deal with the issue of quantity, which the superior also mentions.

A correct decision is often understood by decision-makers as one that one manages to get past the superior and-in case of an appeal-past the court. Thus, decisions that have been double-signed by the heads of units (even if the caseworkers know that their superiors do not always check their decisions very closely) and decisions that have been affirmed by the court are often quasi automatically perceived to be correct. When superiors check decisions, they pay particular attention to whether the decision is legally correct, whether it adheres to institutional practice and whether its argumentation is solid.

For a decision to be considered legally correct it must be consistent with the Swiss Asylum Act, the Federal Act on Foreign Nationals, the 1951 Refugee Convention and the rulings of the court. What 'according to institutional practice' means, on the other hand, is contested and keeps

\footnotetext{
${ }^{6}$ Miaz and Affolter also did fieldwork in the Federal Administrative Court. Furthermore, Miaz included legal advice offices in his research.

${ }^{7}$ Nora, head of unit, headquarters. To protect the anonymity of our interaction partners, all names are pseudonyms.
} 
changing over time. Officially, institutional practice refers to the Asyl- und Wegweisungspraxis (practice of asylum and expulsion; APPAs), the institutional guidelines on how to decide asylum cases from specific countries or regions and with specific flight motives. ${ }^{8}$ However, we argue that institutional practice encompasses more than is explicitly stated in these guidelines, namely the collective ways for taking specific decisions within different communities of interpretation in the office. This is illustrated by the following quote, in which a caseworker speaks about decision-making in the different reception centres and the headquarters:

Carmen: Sometimes we apply different measurements. And then it's kind of a legal inequality. For example, we [reception centre A] once had a lot of [people from country Y]. With 'country tests' and everything we tried to expose them and to show that they did not really come from [country $\mathrm{Y}$ ]. So, we started rejecting their claims. At the same time in [reception centre $B]$ they were doing interviews and just waving them through [quickly giving them positive decisions]. Just because the practice had not been coordinated. It got going after a while, but it always takes an outcry first that something is going wrong to get something going [...].

Researcher: But don't you have the APPAs, which define what the common practice is?

Carmen: Yes, [...] but some APPAs are just not up to date. Sometimes we have already moved a step further, but it's not in the APPA yet.

Researcher: So this means you are at liberty to create your own practice here?

Carmen: Yes, of course, but naturally in consultation with those responsible for that country at the headquarters. For example, the case of [people from country Y]; [the practice of giving more negative decisions] started here. We in the reception centres are usually the first ones to pick up new trends. It is here where you just notice them first. ${ }^{\text {? }}$

Several reception centre officials remarked that because they are physically so much closer to the asylum seekers (they are housed in the same building) and it is at the reception and procedure centres where the asylum seekers first arrive, they are better equipped to pick up new trends than the people at headquarters and can thereupon adapt their practice. But because they are

\footnotetext{
${ }^{8}$ The APPAs are created and kept up to date by the Federführung, the person(s) in charge of a particular country at the headquarters in Berne. APPAs exist for the most common countries of origin.

${ }^{9}$ Carmen, caseworker, reception centre.
} 
not in charge of the APPAs and do not hold any Federführungen, ${ }^{10}$ this can result in them taking decisions that seem appropriate to them and trying to get them past the Federal Administrative Tribunal. If they manage to do so, these decisions serve as a kind of confirmation of the 'practice' and may, therefore, lead to the establishment of a new institutional practice. ${ }^{11}$ This shows how caseworkers 'shape and mediate polic[ies] while translating and implementing [them] into action' (Wedel et al. 2005: 34).

As mentioned at the beginning of this section, rulings by the Federal Administrative Court constitute a further means for measuring correctness. Hence, the units and divisions of the SEM keep records of how many of their employees' decisions are quashed and for what reasons. A distinction is made between quashings that could have been avoided and those that could not have been and are, therefore, not really perceived as mistakes. Avoidable quashings are those occurring because of so-called 'formal' mistakes SEM caseworkers had made, for instance, not granting the asylum seeker the proper right to be heard or not making all the necessary enquiries. In contrast, quashings on the basis of the court judging the credibility of asylum claims or the scope of the refugee definition differently than the SEM official did, are regarded as unavoidable. If individual caseworkers and/or units receive too many quashings, especially of the 'avoidable' kind, this is conceived of as bad decision-making. Not only do such quashings reflect badly on the quality of decision-making, they also cost time (and money) and, therefore, stand in the way of efficient decision-making.

Efficiency plays an important role in decision-making. Thus, decision-makers' work is not only checked in so-called qualitative terms, but also in quantitative ones. 'Somehow we are always confronted with this dilemma (in diesem Clinch) of not just having to demand qualitatively correct work from our people, but also that it 'yields a profit' (es muss auch etwas rausschauen )', ${ }^{12}$ said Markus, a head of unit at the headquarters. With 'yielding a profit' he was referring to the institutional demand to produce so-called 'output'. This focus on numerical accountability is typical of contemporary (asylum) administrations (see Gill 2016: 39; Poertner 2017). Quantitative targets are set on a regular basis for the whole institution. There is a lot of (political) pressure to deal with asylum applications fast and reduce the

\footnotetext{
${ }^{10}$ In German, 'die Federführung haben' means 'to have the lead'. Here it refers to the person or the group of people responsible for determining a country or thematic practice doctrine.

${ }^{11}$ Of course, this is not something that is only done by officials working in the reception centres but also those at the headquarters.

${ }^{12}$ Markus, head of unit, headquarters.
} 
number of pending cases. Setting quantitative targets is a way of doing justice to these demands. ${ }^{13}$ This political pressure for efficiency becomes apparent in the statement by the same superior, Markus, that 'we [the SEM (officials)] have a responsibility towards the Swiss people and the tax payers to not just take correct decisions but decisions of "the right quality". He then goes on to say: 'And I deliberately speak of "the right quality" and not of "optimal quality", because it could always be done better'. ${ }^{14}$ With 'right quality' Markus implies that the efforts invested to make decisions qualitatively better has to be measured against the quantitative demands of the office: it is not only important for decisions to be correct and thorough, but the time and effort involved matter too. That Markus considers this to be a political demand becomes apparent through the reference he makes to 'the Swiss people' and 'the tax payers'. Markus appears to have internalised a certain sense of accountability towards these imagined, generalised and blurred figures. In caseworkers' and their superiors' discourses, these two figures are usually used to justify restrictive practices and the measures for a greater productivity.

The concept of 'the right quality' bridges quantitative and qualitative demands. Doing one's job well in the SEM means making an adequate effort. It requires 'practical knowledge' to be able to assess for each specific case what 'adequate' means. Overall, it means going into sufficient depth when dealing with a case, but not investing more time and resources than necessary. This can be seen in the example of Theodor, a caseworker, who said that his superior had instructed him to stop always looking for material evidence in order to argue for the non-credibility of asylum claims using the criterion 'contradiction to facts' (Tatsachenwidrigkeit). The superior considered this too time-consuming and had asked him to focus instead on framing his arguments along the lines of 'insufficient substance', which could be done on the basis of the asylum interview minutes alone. The example shows that out of all the possible legal ways to argue in a case the most economical ones are usually promoted.

\footnotetext{
${ }^{13}$ While many of the caseworkers who had been working at the SEM for more than 15 or 20 years told us that there had always been numerical measures, most of them felt the output pressure had increased over recent years.

${ }^{14}$ Markus, head of unit, headquarters.
} 


\section{Negotiating 'Fairness'}

Corinna: I limit myself to [applying institutional practice], because I have to. Even if sometimes it doesn't reflect my personal opinion. [But] sometimes we also have to think like a human being and not like a person who makes the law. ${ }^{15}$

Nora: For me being 'fair' means that we use the same standards for evaluating each claim. This also means that if the applicant does not fulfil the eligibility criteria we don't 'bend the rules' [drehen und biegen] and write a positive decision, just because it's quicker. It means that when we reach the conclusion that the case must be rejected, we take the trouble to write a negative decision, even if this takes us three to four days, and if one had just said 'yes, it's coherent', it might only have taken half a day. That's what it means to be 'firm but fair' [in der Härte gerecht]. On the other hand, we try hard to do justice to each individual case, each individual problem. I can also sometimes 'turn a blind eye' [fünf gerade sein lassen] if my gut feeling tells me that I shouldn't be obstinate and that I should try to do justice to the individual case. [...] it means that we will look at the case more closely and that we do not hide behind formal arguments too readily. ${ }^{16}$

We start with these two quotes because they show similar patterns regarding what is perceived as fair decision-making. Both officials stress the importance of following rules (stemming from the law and institutional practice). This is often described as being 'firm' or 'strict', which are regarded as necessities and virtues. For Nora being firm means treating everyone equally, which she (and many others) believe is what asylum decision-making should be about. Both also seem to imply that not (strictly) following the rules should constitute an exception. Corinna describes these 'exceptional' moments as situations in which one thinks 'like a human being'. For Nora these exceptional moments arise when her gut feeling tells her to deal with a case more closely than usual. Both of them, therefore, imply that not only legal and organisational norms and constraints orient decision-makers' practices but also moral considerations, emotions and feelings.

However, in this section we go beyond this dialectical depiction by extending the story in two ways. First, we argue that dealing with this 'dilemma' (whether it is perceived as such by the caseworkers or not) is not ('just') about using one's room for manoeuvre to either 'be compassionate'

\footnotetext{
${ }^{15}$ Corinna, asylum caseworker, headquarters.

${ }^{16}$ Nora, head of unit, headquarters.
} 
or 'follow the law', but about making these demands meet. Second, we argue that the tension between what we call 'doing justice to the individual' and 'doing justice to the system' is about more than just 'compassion' and 'impartial rule-following'. It is about finding one's position in a 'moral economy' (Fassin 2012: 441) fraught with pitfalls on various grounds: upholding legal and formal considerations without falling into the trap of becoming overly formalistic; seeing your room for manoeuvre in the right spots-whether in your fight against abuse or to provide protection to as many as possible; coping with being regularly lied to as well as being exposed to excruciating stories of suffering. No simple solution to these tensions exists, but caseworkers struggle in justifying their own position in this field of contradictory convictions on what 'just' decision-making ultimately means. We argue on the basis of this that decision-makers not only have an idea of what is 'just' in an individual case, but develop a representation about the 'rightful' positioning in this landscape of contested moral measures.

Decision-makers' volitional allegiance to (parts of) the office and the important role that 'protecting the system' plays in their work are crucial in this regard. Caseworkers often tend to refer to 'the system' and their affiliation to it when explaining why they have to be strict in their application of the law. In Switzerland, like other countries of the global North, discourses on 'abuses' and on 'bogus' refugees loom large (Zimmermann 2011). The work of asylum caseworkers is, thus, marked by suspicion concerning asylum seekers' motives for applying for asylum, which becomes particularly visible in credibility assessments. They argue that they have to refuse those asylum seekers who do not correspond to the legal definition of the refugee in order to protect the asylum institution from abuse, to preserve the credibility of the system and, finally, to continue to protect 'those who deserve protection', as this quote nicely shows:

I think that saying 'no' to someone who's not a refugee in the sense of the UNHCR and of the Refugee Convention contributes to the protection of the asylum institution. One has to say 'no' to those who are not refugees in order to be able to say 'yes' to those who are. ${ }^{17}$

Fassin and Kobelinsky (2012: 465) relate these kinds of legitimation narratives back to the historical change in decision-making, when in the mid

${ }^{17}$ Johann, asylum caseworker, headquarters. 
1980s most requests went from being granted to being rejected. They argue that the 'only morally acceptable means to solve this problem is to make a separation between valuing asylum while devaluing those who claim it'. Decision-makers

not only believe that they do good work, in which they sincerely believe, but are also convinced that they do it even better when they are more scrupulous in their examination of claims and parsimonious in granting refugee status. (ibid.)

Decision-makers, therefore, tend to make use of explanations such as the one quoted above to explain how they do justice both to the system, and to the individual asylum seeker. Whilst some decision-makers told us that doing justice to the system and doing justice to the individual asylum seeker created a dilemma they had to deal with in their daily work, many seemed to agree with the idea that 'just' decision-making was about bringing doing justice to the individual asylum seeker into accordance with doing justice to the system. The quote above shows how this is done.

The meanings ascribed to fair decision-making so far pertain to legal equality. A further meaning often associated with fair decision-making is that of impartiality, as Nora's quote at the beginning of this section indicates. The ideal of fair decision-making is, therefore, commonly understood to be about finding one's middle ground, as this quote shows:

We sometimes tease each other a bit. If one of us takes a rather strict decision: 'Oh, what a hardliner'. And if someone says that they had to turn a blind eye or take an 'in dubio pro [refugio]'18 decision: 'What a wimp you've become'. I think it's important to find a middle ground somewhere. So, that you don't slide towards one extreme, you see? ${ }^{39}$

It is very common within the office to denounce other decision-makers, asylum units, divisions and even centres as being either 'softies' or 'hardliners'. Who is considered to be a 'softy' or a 'hardliner', and what that constitutes, vary. What some consider impartial decision-making, might already be regarded as the act of a 'softy' by others. In the following quote Jenny

\footnotetext{
${ }^{18}$ This means to give the applicants the 'benefit of the doubt'.

${ }^{19}$ Lucy, asylum caseworker, headquarters.
} 
criticises 'leftists', who are often considered to be 'softies' for pursuing egoistic projects:

And then there are those that one knows are totally left-wing and would like to save the world. And they think they've done something good [by 'just waving those people through' on the basis of family reunification], even though some of these 16 and 17-year old women disappeared and never officially arrived here. [...] That's very egoistic [...] and frowned upon, you see? Because it's 'professionally' [fachlich] just completely wrong and also legally. I mean, that's just so problematic. ${ }^{20}$

Jenny uses this example to show why for her doing what one feels to be 'personally right' fails to do justice to the individual. She, thus, gives a twist to the narrative of why rightful decision-making should be orientated towards what is professionally and legally right, which extracts the moral basis from narratives that justify decision-making focusing on individual suffering. Attitudes like Jenny's are, however, also criticised by decision-makers. They blame their co-workers (and/or themselves) for not being open enough towards asylum seekers and their individual circumstances and for having become 'cynical', 'overly formalistic' and what they sometimes call 'law machines'.

Both kinds of criticism seem to involve an inherent assumption that 'just' decision-making implies making personal convictions, feelings, ethics and notions of ethos fit. However, how this is to be achieved-whether it is about putting different notions of 'just' decision-making into a hierarchical order, what this order should be, and, thus, how different ideas of what makes decision-making 'just' should be weighted—or whether it is about merging personal and professional ideas of the 'just decision' and to what extent this is desirable-is a matter of contestation. This leads to tensions that decision-makers often experience and have to deal with in the course of their everyday work. How they deal with it, may, in turn, depend on caseworkers' different affiliations and allegiances, on the one hand, but also on the particular situation: the case they are dealing with and the person they are talking to.

${ }^{20}$ Jenny, head of unit, reception and procedure centre. 


\section{Communities of Interpretation}

I have to do what the office says, otherwise I will somehow betray the office and I don't want that either. ${ }^{21}$

The expression of 'betraying the office' in this quote suggests a close affiliation between the official and the office that, we suggest, cannot be taken for granted. It implies a struggle for the ideologically affected desires of state personnel' (Gill 2009: 215), their 'volitional allegiance' (ibid.) with the office (also standing for 'the system'). It is important, however, not to perceive the office solely as a unified whole. Rather, it appeared to us to be divided along complicated and evolving lines of affiliations and allegiances. These changing allegiances profoundly influence what 'just' decision-making means for caseworkers in particular situations. Thus, decision-makers align with what are imagined as 'just decisions' in the communities of interpretation they identify themselves with and are identified with, and distance themselves from other senses of 'just' decision-making.

These communities of interpretation evolve along the fissures between units, divisions, professions, experience, and hierarchy, and are crucial in order to grasp how notions of 'just' decision-making develop and become shared amongst different subdivisions of the office. However, we acknowledge that these fissures are not dividing lines: they are, to some extent, situational: not only are they complicated and evolving, but sometimes the fissures run right through individuals that feel torn between competing senses of 'just' decision-making. Also, there is arguably more mutual understanding between the various divisions than this rather antagonistic representation allows us to acknowledge. Officials in the office are affiliated to multiple 'communities' and may 'change sides'. In this part we show contestations between different communities of interpretation evolving around the role of expertise and experience for correct and fair decision-making as well as around the importance of a legal approach versus so-called intercultural sensitivity and of compassion.

Nearly all caseworkers we spoke to in the reception centres tended to identify themselves primarily with their centre rather than with the SEM as a whole. In our conversations with them they often mentioned why they thought the work they did was better-in the sense of being more correct and fairer-than that of decision-makers working at the headquarters.

\footnotetext{
${ }^{21}$ Corinna, asylum caseworker, headquarters.
} 
The latter did the same. Decision-makers, both in the reception centres and at headquarters, considered it to be unfair that their decision-making sometimes differed. However, in order to overcome these differences they all expected the respective other to adapt to their way of doing things. Officials in the reception centres often highlighted that people at the headquarters in Bern were not as close to the claimants as they were. They used this closeness to the claimants to explain their own different, more 'realitygrounded' approach to decision-making. Officials in the headquarters, in turn, expressed reservations about practices in the reception centres that they considered to be 'shirt-sleeved' or 'rush rush' approaches, that suffered from a lack of either distance from the claimants or the necessary expertise. At stake here are different notions of 'expertise' that are considered necessary for correct and fair decision-making. Officials in the reception centres perceive their expertise to derive from their 'close contact' with asylum seekers and the vast number of conversations they have with them (since they conduct both the short and long asylum interviews, whilst the decision-makers in Bern only do the latter). Many decision-makers at the headquarters, on the other hand, consider their expertise to be greater and of more value, because they hold all the Federführungen and, therefore, have all the experts and their expertise 'in house'.

Daniel: Those in the 'country teams' they're supposed to be the specialists. But then someone who's been working at the SEM for half a year or so tells you what to do. Well [...].

Researcher: You mean that someone who's new takes on a Federführung?

Daniel: Yes, exactly. [...] To give you a specific example; I once interviewed a woman from Somalia. She couldn't [tell me] anything. So I asked the Federführung in Bern how this works with Somali women, whether I could give her a removal order. And then someone [from the Federführung] wrote back to me and said: 'As a women she [belongs to] a vulnerable group'. As a woman you're not per se vulnerable. [...] I didn't do it. I gave her a removal order anyway. And I was backed up. ${ }^{22}$

Here we see a caseworker from a reception centre challenging the expertise and authority of a colleague at the headquarters. In this case, he simply does not follow her advice. Furthermore, the friction between newcomers or 'inexperienced' decision-makers and old-established officials becomes apparent in his statement.

${ }^{22}$ Daniel, asylum caseworker, reception centre. 
Newcomers sometimes accuse old-established officials of having developed a 'cynical' attitude towards asylum applicants over the course of their career that they deem incompatible with rightful decision-making. Although they often express a certain understanding for developing cynicism and even sometimes state that nobody should do this job for too long, they are most impressed by old-established officials who have managed to maintain the ability to 'see the humans behind applications' and to make an effort to 'reset' after every interview, approaching 'every asylum applicant as if she or he were the first'. Old-established officials, in turn, are sometimes sceptical of approaches to decision-making that they consider put personal opinions and feelings above the values of the larger 'community of interpretation', the office. Instead, they feel that some of the newcomers pursue 'egoistic projects'. Hence, whilst experience is regarded by newcomers and oldestablished officials alike as essential for decision-making, experience is also believed to sometimes stand in the way of 'just' decision-making.

However, what 'seeing the human behind the application' means in practical terms is contested. What for some might fall within 'seeing the human, instead of a number', might already be regarded as 'egoistic' and 'unfair' by others as we showed in the previous section. These differences in decision-making are often related back to decision-makers' political opinions, and also - more often — to their units, divisions or centres being 'softer' or 'harder'.

Furthermore, in the office, different professional backgrounds of caseworkers and superiors are also mentioned as indicative of diverging perspectives on what correct and fair decision-making is. The main fault line seems to run between those with a legal background and those without, the latter usually having a social sciences or humanities background. As the asylum procedure involves writing legal orders, conducting interviews in complex intercultural settings (see Kälin 1986) and evaluating the credibility of asserted origin and persecution narratives, caseworkers often disagree on what 'just' decision-making means regarding these contrasting facets of their work. Thus, caseworkers quite often openly acknowledge taking a 'legalistic' approach or one that departs from it and express a clear preference for one way or the other. Of course, this is not only related to their professional background, but also to how they have been trained and socialised in the asylum office. Hence, whilst some superiors expressed a clear preference for employing new decision-makers who are legally versed and/or have a legal background, others prefer people who have travelled, 'who know how things work abroad - not just in Russia, America or France, but in Bangladesh or Uganda for example - [and] who can free themselves from a eurocentric 
perception'. ${ }^{23}$ These different employment strategies and the fact that the superiors themselves employ their decision-makers, explain to some extent why the different asylum units become important communities of interpretation. Of course, this also has to do with the hierarchical structure; with the superiors checking their employees' decisions and deciding whether they are correct or not; and with decision-makers being trained on the job within the units.

A further fault line of affiliation and allegiance-one that is not specific to the asylum office but haunts most hierarchical bureaucratic organisations in some form or other-is that between the management and frontline staff or 'street-level bureaucrats' (see Lipsky 2010). While the former are concerned with broader strategic planning, organising the work of the latter and 'steering' the processes and outcomes of the whole, the latter are those typically meeting 'clients', processing cases and taking decisions in individual cases. A main tension in the office, as discussed above, arises between the management emphasising numbers and output and frontline staff who consider an (over-)emphasis on numbers problematic if not counterproductive to the complex work they do.

Vast differences seem to exist in the ways in which heads of divisions and units pass on the pressure to yield numbers to their subordinates: while some actively shield their staff from too rigid output target enforcement, others seem less able or willing to do so. And, as the following example highlights, they may themselves feel pressured or inclined to put the output first for career reasons or out of fear of losing their position:

It appears quite markedly; we're only human. Now, for example: The head of division of the asylum procedure was only appointed ad interim and then they said: 'Well, maybe he will then be appointed but maybe it [the position] will also be advertised'. And then he got really stressed out and he had to produce as good numbers as possible. So, he sat down with all the head of units and then they said: 'What do we do now? We really have to increase the output, now that we've hired so many new people, now it has to rise'. [...] It's quite logical that these people are not efficient in the first three, four months and that the output rather decreases if the more experienced ones have to instruct the new people, if they come with questions, and they have to teach modules and so on. And this is logical, everybody knows that, actually in every operational management this is clear except, apparently, in the SEM, where one is afraid of the pressure, and of politics and such things, because these Swiss

${ }^{23} \mathrm{Nadia}$, head of unit, headquarters. 
Federal Councillors ${ }^{24}$ probably need to show results soon, and therefore one has decided, well yes, we have to increase the output. ${ }^{25}$

This example nicely shows that even if output goals are frowned upon on the street-level, caseworkers try to make sense of the rationalities behind them. That does not mean, however, that they see them as 'necessary' and unavoidable as they feel the management sometimes implies. And, more importantly, it shows that they see them as a barrier that gets in the way of what they consider 'just' decision-making.

\section{Conclusion}

'Always remember: you are the office', new decision-makers are constantly reminded in the training sessions. Thus, the expectation is that they should think and behave like that and not like individuals. They are asked and instructed to follow the objectives of the office, which — with it being a state institution-we can also call 'state objectives'. The meanings ascribed to 'just' decision-making by caseworkers and superiors that we have discussed in this chapter seem to be very much in line with these objectives. Following Gill (2009: 219), we argue that 'states [...] command powers that are capable of engendering the will to act in accordance with state objectives, rather than simply generating the necessity or imperative to do so'. We argue that the need and wish to 'fit in' plays an important role in this regard. Above we described the widespread denunciation of other decision-makers as well as whole units, divisions and centres as being either 'hardliners' or 'softies'. Most decision-makers do not want to be denominated as either, especially if the denomination does not fit with that of the community or communities of interpretation they most identify with. When taking decisions, therefore, caseworkers not only try to anticipate their superior's take towards their decisions, but sometimes also worry about what their peers might think about them, as this quote shows:

And then this case with 'in dubio pro [refugio]'. Sometimes you feel really bad [doing this]. Because [...] people speak about you behind your back: 'Oh, she chose the easy way out; just quickly taking a positive [decision]. But maybe

\footnotetext{
${ }^{24}$ The seven Swiss Federal Councillors are also ministers. One of them leads the Federal Department of Justice and Police, of which the SEM is a part.

${ }^{25}$ Benjamin, asylum caseworker, headquarters.
} 
you really struggled with [the decision]. Because sometimes, even though the story is not at all convincing, but if you don't find any arguments - truly not and not just out of laziness - your only choice is to take a positive [decision]. Well, ok, maybe you could show the case to someone else first. ${ }^{26}$

This quote is typical in two ways. First, it shows the role one's co-workers-or rather the anticipation of what they might think-play in decision-making. In line with this, many newcomers told us that it was primarily through their 'coaches', 'godmothers' and 'godfathers' - who are co-workers from the same unit that train new employees to do the job-that they learnt how to 'think the right thoughts'. Second, it is not a coincidence that Helen refers to what her co-workers might think with regard to her taking a 'too lenient' decision rather than one that is 'too harsh'. While 'overly strict' and 'cynical' decision-making is also frequently criticised and regarded as bad decision-making, we have never heard it being called 'unprofessional', whereas 'lenient' and so-called 'naïve' decision-making is (see also Alpes and Spire 2014: 269; Fassin and D'Halluin 2005: 6006; Kelly 2012; Scheffer 2003: 456; Whyte 2011).

Being professional and fitting into their communities of interpretation are important for decision-makers. This can help explain decision-makers' volitional allegiance to the asylum office and its objectives and ultimately to 'the state' and its objectives. Through these communities of interpretation things become self-evident, like the need to protect the asylum system from being abused and to save protection for those 'who really deserve it'. At the same time, it seems to be self-evident within the office that decision-makers should always be able to endorse and stand by the decisions they take and the way they go about doing so.

\section{References}

Alpes, J., \& Spire, A. (2014). Dealing with Law in Migration Control: The Powers of Street-Level Bureaucrats at French Consulates. Social and Legal Studies, 23(2), 261-274.

Barnett, C. (2011). Geography and Ethics: Justice Unbound. Progress in Human Geography, 35(2), 246-255.

Breidenstein, G., Hirschauer, S., Kalthoff, H., \& Nieswand, B. (2013). Ethnografie. Die Praxis der Feldforschung. Stuttgart: UTB.

${ }^{26}$ Helen, asylum caseworker, headquarters. 
Doornbos, N. (2005). On Being Heard in Asylum Cases; Evidentiary Assessment Through Asylum Interviews. In G. Noll (Ed.), Proof, Evidentiary Assessment and Credibility in Asylum Procedures (pp. 103-122). Leiden and Boston: Martinus Nijhoff.

Fassin, D. (2012). Moral Economy and Local Justice. Revue française de sociologie, 53(4), 651-656.

Fassin, D., \& D'Halluin, E. (2005). The Truth from the Body: Medical Certificates as Ultimate Evidence for Asylum Seekers. American Anthropologist, 107(4), 597-608.

Fassin, D., \& Kobelinsky, C. (2012). How Asylum Claims Are Adjudicated: The Institution as a Moral Agent. Revue française de sociologie, 53(4), 444-472.

Gibb, R., \& Good, A. (2013). Do the Facts Speak for Themselves? Country of Origin Information in French and British Refugee Status Determination Procedures. International Journal of Refugee Law, 25(2), 291-322.

Gill, N. (2009). Presentational State Power: Temporal and Spatial Influences Over Asylum Sector Decisionmakers. Transactions of the Institute of British Geographers, 34, 215-233.

Gill, N. (2016). Nothing Personal? Geographies of Governing and Activism in the British Asylum System. Oxford: Wiley-Blackwell.

Good, A. (2007). Anthropology and Expertise in the Asylum Courts. London: Routledge-Cavendish.

Gupta, A. (1995). Blurred Boundaries: The Discourse of Corruption, the Culture of Politics, and the Imagined State. American Ethnologist, 22(2), 375-402.

Jubany, O. (2011). Constructing Truths in a Culture of Disbelief: Understanding Asylum Screening from Within. International Sociology, 26(1), 74-94.

Kälin, W. (1986). Troubled Communication: Cross-Cultural Misunderstandings in the Asylum-Hearing. International Migration Review, 20(2), 230-241.

Kelly, T. (2012). Sympathy and Suspicion: Torture, Asylum, and Humanity. Journal of the Royal Anthropological Institute, 78, 753-768.

Kobelinsky, C. (2015). In Search of Truth: How Asylum Applications Are Adjudicated. In D. Fassin (Ed.), At the Heart of the State: The Moral World of Institutions (pp. 67-92). London: Pluto Press.

Laroche, H. (1995). From Decision to Action in Organizations: Decision-Making as a Social Representation. Organization Science, 6(1), 62-75.

Lipsky, M. (2010). Street-Level Bureaucracy, 30th Anniversary Edition: Dilemmas of the Individual in Public Service. New York: Russel Sage Foundation.

Maryns, K. (2006). The Asylum Speaker: Language in the Belgian Asylum Procedure. The International Journal of Speech, Language and the Law, 14(2), 295-300.

Maynard-Moody, S., \& Musheno, M. (2003). Cops, Teachers, Conselors. Stories from the Front Lines of Public Service. Ann Arbor: University of Michigan Press.

Miaz, J. (2017). From the Law to the Decision: The Social and Legal Conditions of Asylum Adjudication in Switzerland. European Policy Analysis, 3(2), 372-396. 
Mountz, A. (2010). Seeking Asylum. Human Smuggling and Bureaucracy at the Border. Minneapolis: University of Minnesota Press.

Poertner, E. (2017). Governing Asylum Through Configurations of Productivity and Deterrence: Effects on the Spatiotemporal Trajectories of Cases in Switzerland. Geoforum, 78, 12-21.

Probst, J. (2011). Entre faits et fiction: l'instruction de la demande d'asile en Allemagne et en France. Cultures and Conflits, 84, 63-80.

Scheffer, T. (2001). Asylgewährung: eine ethnographische Analyse des deutschen Asylverfahrens. Stuttgart: Lucius and Lucius.

Scheffer, T. (2003). Kritik der Urteilskraft - Wie die Asylprüfung Unentscheidbares in Entscheidbares überführt. In J. Oltmer (Ed.), Migration steuern und verwalten: Deutschland vom späten 19. Jahrhunder bis zur Gegenwart (pp. 423-458). Göttingen: Vandenhoeck and Ruprecht.

Shore, C., \& Wright, S. (2011). Conceptualising Policy: Technologies of Governance and the Politics of Visibility. In C. Shore, S. Wright, \& D. Però (Eds.), Policy Worlds. Anthropology and the Analysis of Contemporary Power (pp. 1-25). New York, Oxford: Berghahn Book.

Souter, J. (2011). A Culture of Disbelief or Denial? Critiquing Refugee Status Determination in the United Kingdom. Oxford Monitor of Forced Migration, $1(1), 48-59$.

Van Maanen, J. (1982). Fieldwork on the Beat. In J. Van Maanen, J. M. Dabbs, \& R. R. Faulkner (Eds.), Varieties of Qualitative Research (pp. 103-151). Beverly Hills, London, and New Delhi: Sage.

Wedel, J. R., Shore, C., Feldman, G., \& Lathrop, S. (2005). Toward an Anthropology of Public Policy. Annals of the American Academy of Political and Social Science, 600, 30-51.

Wenger, E. (2003). Communities of Practice and Social Learning Systems. In D. Nicolini, S. Gherardi, \& D. Yanow (Eds.), Knowing in Organizations: A PracticeBased Approach (pp. 76-99). Armonk, NY: M.E. Sharp.

Whyte, Z. (2011). Enter the Myopticon. Uncertain Surveillance in the Danish Asylum System. Anthropology Today, 27(3), 18-21.

Zimmermann, S. E. (2011). Reconsidering the Problem of "Bogus" Refugees with "Socio-economic Motivations" for Seeking Asylum. Mobilities, 6, 335-352. 
Open Access This chapter is distributed under the terms of the Creative Commons Attribution 4.0 International License (http://creativecommons.org/licenses/ by/4.0/), which permits use, duplication, adaptation, distribution and reproduction in any medium or format, as long as you give appropriate credit to the original author(s) and the source, a link is provided to the Creative Commons license and any changes made are indicated.

The images or other third party material in this chapter are included in the work's Creative Commons license, unless indicated otherwise in the credit line; if such material is not included in the work's Creative Commons license and the respective action is not permitted by statutory regulation, users will need to obtain permission from the license holder to duplicate, adapt or reproduce the material. 